AGRICULTURE AND BIOLOGY JOURNAL OF NORTH AMERICA

ISSN Print: 2151-7517, ISSN Online: 2151-7525, doi:10.5251/abjna.2011.2.8.1244.1250

(C) 2011, ScienceHuß, http://www.scihub.org/ABJNA

\title{
Suitability of extractants for predicting iron in soils of the humid zone of South-Western Nigeria
}

\author{
Aaron S. Tening ${ }^{* 1}$ and John A.I. Omueti ${ }^{2}$ \\ ${ }^{1}$ Department of Chemistry, University of Buea, P.O. Box 63, Buea, Cameroon \\ ${ }^{2}$ Department of Agronomy, University of Ibadan, Ibadan, Nigeria. \\ ${ }^{*}$ Corresponding author: Tel.: +237 77753400 \\ E-mail: suhtening@yahoo.com
}

\begin{abstract}
Iron (Fe), a micronutrient, is currently being determined using extractants that were developed for homogeneous temperate soils. Considering the fact that tropical soils are largely heterogeneous and may not conform to conditions that apply to temperate soils, there was a need to have an extractant that will be able to meet the requirements of tropical soils. The Fe content of twenty soils across the humid zone of South-Western Nigeria were determined by Diethylenetriamine pentaacetic acid (DTPA), $0.1 \mathrm{~N}$ hydrochloric acid $(\mathrm{HCl})$ and sodium hypochlorite $(\mathrm{NaOCl})$ buffer methods. The test crop was maize (Zea mays L.). There was a significant $(p<0.05)$ positive correlation between dry matter and $\mathrm{Fe}$ content in the plants. Iron extracted by $\mathrm{NaOCl}$ buffered at various $\mathrm{pH}$ levels was highly correlated $(p<0.01)$ with Fe extracted by the conventional extractants (DTPA and $0.1 \mathrm{~N} \mathrm{HCl}$ ). A weak positive non significant $(p>0.05)$ correlation with plant Fe uptake for $\mathrm{NaOCl}$ buffered at $\mathrm{pH} 8.0$ was found to be superior to those of DTPA and $0.1 \mathrm{~N} \mathrm{HCl}$. Because of its availability and the simplicity of the extraction procedure, $\mathrm{NaOCl}$ buffered at $\mathrm{pH} 8.0$ could be used as a replacement for DTPA and $0.1 \mathrm{~N} \mathrm{HCl}$.
\end{abstract}

Key words: Sodium hypochlorite, Extractants, Iron, Soils, Humid zone

\section{INTRODUCTION}

Iron, a micronutrient, is necessary for the synthesis and maintenance of chlorophyll in plants and is an essential component of many enzymes. Iron has been found to be toxic in certain low-land rice conditions, while with upland rice, it has been found to limit yield (Agboola and Fube, 1982). Kang et al. (1976) observed Fe chlorosis in upland rice grown on land after intensive burning of plant residues. Tenday-old maize plantlets grown without Fe displayed severe alterations, with a $50 \%$ decrease in Fe and chlorophyll concentrations (Thoiron et al., 1997). These authors also reported that two polypeptides from the microsomal fraction of leaves were found to be repressed under Fe-deficiency conditions. Chaignon et al. (2002) reported that Fe deficiency resulted in elevated acquisition of copper $(\mathrm{Cu})$ from a $\mathrm{Cu}$ contaminated soil. They attributed this to enhanced phytosiderophore release.

The status of $\mathrm{Fe}$ in soils and its availability to plants is therefore the result of a complex set of factors related to parent material, soil type, soil $\mathrm{pH}$ and climate. Aubert and Pinta (1977) reported the existence of a strong relationship between parent material and micronutrient content of soils in tropical Africa. Cottenie et al. (1981) noted that Nigerian soils derived from basic rocks such as basalt and amphiboles are richer in $\mathrm{Fe}$ than those derived from acid granites and sandstones. Because of this sensitivity of $\mathrm{Fe}$ to environmental conditions and due to the fact that plants need it only in small amounts, its concentration relative to crop production is often difficult to measure. Considering the fact that tropical soils are highly heterogeneous both in chemical and physical properties, routine extractants, developed for homogeneous temperate soils, may not perform up to expectation when used on these soils. There is therefore need in soil testing for local extractants that could be readily available and suitable to the prevailing conditions.

Sodium hypochlorite has been successfully used in the destruction of organic matter in tropical soils (Omueti, 1980; Omueti, 1981) and in temperate Canadian soils (Lavkulich and Wiens, 1970). Other elements particularly manganese $(\mathrm{Mn}), \mathrm{Fe}$ and zinc $(\mathrm{Zn})$ were also extracted with sodium hypochlorite in appreciable amounts (Omueti, 1981). The objective of this study was to compare the $\mathrm{NaOCl}$ extractant with extractants currently employed in most 
laboratories in the humid zone of South-Western Nigeria for the extraction of available Fe.

\section{MATERIALS AND METHODS}

Twenty surface soil samples $(0-15 \mathrm{~cm})$ were collected in the humid zone of South-Western Nigeria (latitudes $6^{\circ} 42^{\prime} \mathrm{N}$ and $7^{\circ} 26^{\prime} \mathrm{N}$; longitudes $3^{\circ} 12^{\prime} \mathrm{E}$ and $\left.5^{\circ} 00^{\prime} \mathrm{E}\right)$. The locations were selected to cover a wide range of soil types and land-use systems (Table 1). The soil samples were air-dried and crushed to pass a 2-mm sieve. The soils were analysed for $\mathrm{pH}$ (soil: water ratio of 1:2.5), available phosphorus (Avail. P), organic carbon (Org. C), total nitrogen (Tot. N), exchangeable bases ( $\mathrm{Ca}, \mathrm{Mg}, \mathrm{Na}$, and $\mathrm{K}$ ), exchangeable acidity and effective cation exchange capacity (ECEC), base saturation, and particle size distribution by methods largely described by Jackson (1958).

The $0.005 \mathrm{M}$ DTPA-extractable Fe was evaluated as described by Lindsay and Norvell (1978). Zero point one normal hydrochloric acid-extractable $\mathrm{Fe}$ was determined using a 1:10 soil to acid solution (IITA, 1979). Before extraction, the $\mathrm{NaOCl}$ was adjusted to $\mathrm{pH} 5.5,6.0,6.5,7.0,8.0$ and 9.5. The lowest $\mathrm{pH}$ range was chosen based on the fact that soluble $\mathrm{Fe}$ level reaches a minimum in the $\mathrm{pH}$ range of 6.5-8.0 (Lindsay, 1972). The highest limit was the level at which this solution was used in organic matter destruction (Omueti, 1980). At the different $\mathrm{pH}$ levels, $\mathrm{NaOCl}$-extractable $\mathrm{Fe}$ was achieved using a $1: 2$ soil to salt solution. Five grams of each soil sample was weighed in six replicates and transferred into $50 \mathrm{~mL}$ plastic centrifuge tubes. Ten $\mathrm{mL}$ of $\mathrm{NaOCl}$, buffered at the specified $\mathrm{pH}$ levels, were added to the soil samples. The soil-to-salt solutions were heated over a boiling water bath for $15 \mathrm{~min}$., and the suspensions were centrifuged for $15 \mathrm{~min}$. at $2000 \mathrm{rpm}$. The extract was filtered with Whatman filter paper (size 42) and Fe was determined using an atomic absorption spectrophotometer.

Four hundred grams of each of the twenty sieved soil samples were weighed out into $500-\mathrm{mL}$ plastic pots in duplicates. A basal dressing of $10 \mathrm{~mL}$ of recommended chemical compounds (Tening et al., 1995), except Fe, was given to each of the pots. The soils were watered to about field moisture capacity with deionised water and allowed to stand for about $48 \mathrm{~h}$ in the greenhouse. Six grains of maize (Zea mays L.) were planted per pot and later thinned to four seedlings per pot after germination. Field moisture capacity was maintained by regular watering with deionised water. Harvesting of all the above ground parts was done four weeks after planting. The harvested maize tops were oven-dried at $80^{\circ} \mathrm{C}$ and weighed when constant weight was attained. The dried plant materials were ground in a Karl Kolb mill to pass through a 20-mesh screen. One gram of each sample was digested in a fume cupboard using a mixture of concentrated nitric acid $\left(\mathrm{HNO}_{3}\right)$, concentrated perchloric acid $\left(\mathrm{HClO}_{4}\right)$, and concentrated sulphuric acid $\left(\mathrm{H}_{2} \mathrm{SO}_{4}\right)$ in the ratio 5:1:1 until a colourless liquid was obtained. (AOAC: Association of Official Analytical Chemists, 1970). Each digested sample was made up to $20 \mathrm{~mL}$ with deionised water (Pauwels et al., 1992) and analysed for $\mathrm{Fe}$ using an Atomic Absorption Spectrophotometer (AAS). Iron uptake was calculated as the product of the concentration of $\mathrm{Fe}$ in the plant tissue and the dry matter yield.

Simple correlation coefficients $(r)$ at different probability levels were used to show the relationships between the different extractants and the extractants and plant Fe uptake.

\section{RESULTS AND DISCUSSION}

The $\mathrm{pH}$ ranges from 5.5 to 6.9 with an average of 6.1 , suggesting that the soils are moderately acidic in nature (Table 2). The percent organic matter of the soils has a range of $0.4-5.1 \%$ and an average of $2.3 \%$. Most of the soils are low in organic matter. The ECEC varies widely with a range of $1.8-15.2$ $\mathrm{cmol} \mathrm{kg}^{-1}$ and an average of $4.2 \mathrm{cmol} \mathrm{kg}^{-1}$. The ECEC of most of the soils is below $5 \mathrm{cmol} \mathrm{kg}^{-1}$, which is the critical value for soils that are dominated by oxide and hydroxide clays under neutral conditions (Olaitan et al., 1984). This fact is supported by the slightly acidic $\mathrm{pH}$ of all the soils (Table 2). The majority of the soils will therefore have few exchange sites. The relatively high ECEC of sample number 11 (15.2

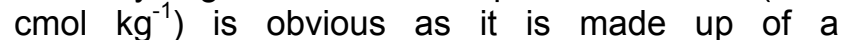
hydromorphic soil with high clay content (Table 1). The carbon-iron ratios of all the soils are above the critical level of 30 at which organic complexes become insoluble (Burrman, 1985). Most of the soils are coarse textured and the textural class ranges from loamy sand to sandy loam.

Soil sample number six consistently gave the highest values of Fe test with all the extractants (Table 3 ). This might not be unconnected to the high content of $\mathrm{Fe}$ originating from the management practices around the area. This area, being a lowland and under palms, will definitely suffer from waterlog. Mandal (1961) reported an increase in Fe solubility in waterlogged soils as a result of organic matter 
addition. This was attributed to the fact that dissociated carboxyl and phenolic groups of podzol humus are able to bind di- and trivalent cations (Schnitzer and Skinner, 1965). Agboola and Fube (1982) also observed Fe toxicity under lowland rice conditions. Banjoko (1981) reported a drop of Fe from $10 \mathrm{mg} \mathrm{kg}^{-1}$ under wet soil condition to about 1 $\mathrm{mg} \mathrm{kg}^{-1}$ or less when the soil was air-dried. Under conditions of poor drainage the reduction of ferric-iron to the more mobile ferrous form can give rise to redistribution of the element within the soil (Bimie and Paterson, 1991).

There was a wide variation in the amount of $\mathrm{Fe}$ extracted by the conventional extractants and $\mathrm{NaOCl}$ buffered at the various $\mathrm{pH}$ levels (Table 3 ). This could be due, in part, to the interaction of moisture, $\mathrm{pH}$, organic matter and available phosphorous with $\mathrm{Fe}$, which could lead to either deficiency or toxicity (O'Conner et al., 1971; Oertli and Opoku, 1974; Kashirad and Marschner, 1974; Banjoko, 1981; Olson et al., 1981; FAO: Food and Agricultural Organisation, 1983). In most of the soils, $\mathrm{NaOCl}$ buffered at $\mathrm{pH} 5.5$ and 9.5 extracted the least soluble $\mathrm{Fe}$. This is not uncommon as soluble Fe levels reach a minimum in the $\mathrm{pH}$ range between 6.5 and 8.0 (Lindsay, 1972).

The dry matter yield and Fe content of the test plant (Zea mays L.) are presented in Table 4. The results showed that $\mathrm{Fe}$ uptake was less than the one that was extracted by all the selected ectractants (Table 3 ). The dry matter yield and Fe content varied from $3.5 \mathrm{~g} \mathrm{pot}^{-1}$ to $7.5 \mathrm{~g} \mathrm{pot}^{-1}$ with an average of $5.4 \mathrm{~g} \mathrm{pot}^{-1}$ and 15.4 to $44.0 \mu \mathrm{g} \mathrm{g}^{-1}$ with an average of $25.4 \mu \mathrm{g} \mathrm{g}$ 1 , respectively.

Iron extracted by $\mathrm{NaOCl}$ buffered at various $\mathrm{pH}$ levels was highly correlated $(p<0.01)$ with $\mathrm{Fe}$ extracted by the conventional extractants (DTPA and $0.1 \mathrm{~N} \mathrm{HCl}$ ). (Table 5). The linear correlation coefficients ( $r$ ) of $\mathrm{NaOCl}$ at $\mathrm{pH} 8.0$ versus DTPA and $0.1 \mathrm{~N} \mathrm{HCl}$ for $\mathrm{Fe}$ are 0.67 and 0.63 , respectively. These values are only comparable to those of $\mathrm{NaOCl}$ at $\mathrm{pH} 5.5$ with DTPA and $0.1 \mathrm{~N} \mathrm{HCl}$ but lower than the r-values for the rest of the combinations. This is not unusual as there was a weak correlation $(r=0.23)$ with plant $\mathrm{Fe}$ uptake for $\mathrm{NaOCl}$ at $\mathrm{pH} 8.0$. The weak correlation with plant uptake could partly be due to the fact that at early stage of maize vegetative growth and development, molecular variations induced by iron deficiency do not affect major house-keeping proteins, but probably affect very specific events depending on low abundance proteins (Thoiron et al., 1997). The r-value of 0.23 was found to be superior to those of DTPA $(r=-0.15)$ and $0.1 \mathrm{~N} \mathrm{HCl}(r=-$ 0.29 ). It is not unlikely that DTPA and $0.1 \mathrm{~N} \mathrm{HCl}$ are not suitable for the extraction of Fe from tropical soils which are heterogeneous and acidic in nature. FAO (1983) gave the r-value of DTPA extractable Fe for Nigerian soils as 0.19 . The low value was attributed to the insensitivity of plant $\mathrm{Fe}$ to the soil factors and also the oxidation-reduction conditions of the soils, which determine the behaviour of $\mathrm{Fe}$ in the soils and its availability to plants.

The linear correlation coefficients between the extractants and some soil properties are shown in Table 6. With the exception of DPTA, the r-values, obtained between $\mathrm{Fe}$ extracted by the extractants and $\mathrm{pH}$, were all negative. This showed that $\mathrm{Fe}$ increases with decrease in soil $\mathrm{pH}$. With the exception of $\mathrm{NaOCl}(\mathrm{pH} 5.5)$, Fe had a positive nonsignificant correlation with organic carbon. Similar results were obtained by Nazif et al. (2006) for both $\mathrm{pH}$ and organic matter. Sand had positive, but nonsignificant correlations with the extractants while silt had negative but non-significant correlations with the extractants. This is contrary to other findings (Sharma et al., 1996; Nazif et al., 2006) who found negative and positive but non-significant correlations between iron and sand, and iron and silt, respectively. This deviation could partly be due to the acidic nature of the soils, which are more or less sandy (Tables 1 and 2). But for DTPA, the other extractants gave negative non-significant correlations with clay. This is not unusual as the soils of this sub-region are predominantly kaolinitic (Omueti and Lavkulich, 1988) and therefore $\mathrm{pH}$ dependent. 
Agric. Biol. J. N. Am., 2011, 2(8): 1244-1250

Table 1. General description and physical properties of the humid zone soils of South-Western Nigeria used in this study.

\begin{tabular}{|c|c|c|c|c|c|c|c|}
\hline $\begin{array}{l}\text { Soil } \\
\text { no. }\end{array}$ & Location & Soil series* & Land use system & Sand & Silt & Clay & Textural class \\
\hline & & & & & $-\%-$ & & \\
\hline 1 & ljebu-Ode & Alagba & Cassava (Manihot) & 75 & 10 & 15 & Sandy loam \\
\hline 2 & Itoikin & lju & Cassava (Manihot) & 59 & 16 & 25 & Sandy clay loam \\
\hline 3 & Mudigasi & Alagba & Fallow & 66 & 22 & 12 & Sandy loam \\
\hline 4 & Ibefun & Alagba & Fallow & 81 & 12 & 7 & Loamy sand \\
\hline 5 & llado & lju & Grass (Andropogon) & 69 & 20 & 11 & Sandy loam \\
\hline 6 & ljebu-Ode & Alagba & Oil palm (Elaeis guineensis) & 91 & 4 & 5 & Sand \\
\hline 7 & Eganke & Alagba & Ploughed & 92 & 1 & 7 & Sand \\
\hline 8 & Erinkorodo & Alagba & Ploughed & 79 & 8 & 13 & Sandy loam \\
\hline 9 & Erinkorodo & Alagba & Fallow & 75 & 16 & 9 & Sandy loam \\
\hline 10 & Ikorodu & Hydromorphic & Vegetables (ammaranthus) & 91 & 4 & 5 & Sand \\
\hline 11 & Majidun & Hydromorphic & Fallow (swamps) & 37 & 12 & 51 & Clay \\
\hline 12 & Sango-Otta & Agege & Cocoyam (colocasia spp) & 57 & 16 & 27 & Sandy clay loam \\
\hline 13 & Sango-Otta & Agege & $\begin{array}{l}\text { Sugarcane (Saccharum } \\
\text { officinarum) }\end{array}$ & 58 & 19 & 23 & Sandy clay loam \\
\hline 14 & Ibadan & Iwo & Fallow & 78 & 13 & 9 & Sandy loam \\
\hline 15 & Ibadan & Iwo & $\begin{array}{l}\text { Sweet potato (Ipomoea } \\
\text { batatas) }\end{array}$ & 80 & 11 & 9 & Loamy sand \\
\hline 16 & Ibadan & Apomu & Maize (Zea mays) & 92 & 1 & 7 & Sand \\
\hline 17 & Ondo-Akure & Ondo & Forest & 74 & 19 & 7 & Sandy loam \\
\hline 18 & Oke-Igbo & Okemesi & Forest & 62 & 15 & 23 & Sandy clay loam \\
\hline 19 & Ifetedo & Egbeda & Forest & 30 & 11 & 7 & Loamy sand \\
\hline 20 & Ibadan-Ife & Egbeda & Forest & 34 & 9 & 7 & Loamy sand \\
\hline
\end{tabular}

* Smith and Montgomery (1962).

Table 2. Some chemical characteristics of the humid zone soils of South-Western Nigeria used in this study.

\begin{tabular}{|c|c|c|c|c|c|c|c|c|c|c|c|c|c|}
\hline $\begin{array}{l}\text { Soil } \\
\text { no. }\end{array}$ & $\begin{array}{c}\mathrm{pH} \\
\left(\mathrm{H}_{2} \mathrm{O}\right)\end{array}$ & Avail. $P$ & Tot. N & Org. C & $\begin{array}{l}\mathrm{Fe}^{*} \\
\left(\times 10^{-3}\right)\end{array}$ & $\mathrm{C} / \mathrm{Fe}$ & $\mathrm{Ca}$ & $\mathrm{Mg}$ & $\mathrm{Na}$ & $\mathrm{K}$ & $\begin{array}{l}\text { Exch. } \\
\text { acidity }\end{array}$ & ECEC & $\begin{array}{l}\text { Base } \\
\text { sat. }\end{array}$ \\
\hline & & $\mathrm{mg} \mathrm{kg}^{-1}$ & & & & & & & $\mathrm{cmol} \mathrm{k}$ & & & & $\%$ \\
\hline 1 & 5.7 & 2.4 & 0.12 & 1.4 & 2.9 & 483 & 0.4 & 2.1 & 0.09 & 0.09 & 1.0 & 3.7 & 73 \\
\hline 3 & 5.8 & 1.3 & 0.09 & 1.0 & 1.1 & 909 & 1.1 & 0.5 & 0.13 & 0.19 & 0.4 & 2.4 & 83 \\
\hline 4 & 6.1 & 4.2 & 0.16 & 1.9 & 2.8 & 679 & 3.1 & 0.6 & 0.12 & 0.21 & 0.4 & 4.4 & 91 \\
\hline 5 & 6.1 & 2.4 & 0.13 & 1.6 & 1.7 & 941 & 2.2 & 0.6 & 0.10 & 0.20 & 0.2 & 4.4 & 94 \\
\hline 8 & 5.7 & 12.5 & 0.15 & 1.8 & 1.2 & 1500 & 2.3 & 0.9 & 0.17 & 0.19 & 0.2 & 3.7 & 94 \\
\hline 9 & 6.3 & 4.0 & 0.12 & 1.4 & 1.3 & 1077 & 2.1 & 0.6 & 0.15 & 0.07 & 0.2 & 3.2 & 93 \\
\hline 10 & 6.9 & 114.0 & 0.02 & 0.2 & 5.2 & 38 & 1.7 & 0.5 & 0.15 & 0.17 & 0.2 & 2.8 & 93 \\
\hline 11 & 6.5 & 3.2 & 0.12 & 1.4 & 3.7 & 378 & 10 & 1.4 & 0.22 & 0.41 & 0.2 & 15.2 & 98 \\
\hline 12 & 6.2 & 1.4 & 0.03 & 0.4 & 1.8 & 222 & 1.3 & 0.6 & 0.11 & 0.12 & 0.6 & 2.7 & 78 \\
\hline 13 & 5.9 & 1.6 & 0.16 & 1.9 & 2.0 & 950 & 5.0 & 0.8 & 0.18 & 0.24 & 0.2 & 6.5 & 97 \\
\hline 19 & 6.7 & 15.0 & 0.25 & 2.9 & 0.8 & 3625 & 4.9 & 0.7 & 0.14 & 0.25 & 0.4 & 6.4 & 94 \\
\hline 20 & 6.9 & 7.8 & 0.05 & 0.6 & 1.3 & 462 & 0.8 & 0.09 & 0.77 & 0.20 & 3.2 & 3.2 & 94 \\
\hline
\end{tabular}

${ }^{*} 0.1 \mathrm{~N} \mathrm{HCl}$ extractable Fe. 
Agric. Biol. J. N. Am., 2011, 2(8): 1244-1250

Table 3. Soil test values for iron using the selected extractants.

\begin{tabular}{|c|c|c|c|c|c|c|c|c|}
\hline \multirow[t]{2}{*}{ Soil No. } & \multirow[t]{2}{*}{ DTPA } & \multirow[t]{2}{*}{$0.1 \mathrm{~N} \mathrm{HCl}$} & \multicolumn{4}{|c|}{$\mathrm{NaOCl}$} & \multirow[b]{2}{*}{$\mathrm{pH} 8.0$} & \multirow[b]{2}{*}{$\mathrm{pH} 9.5$} \\
\hline & & & $\mathrm{pH} 5.5$ & $\mathrm{pH} 6.0$ & $\mathrm{pH} 6.5$ & $\mathrm{pH} 7.0$ & & \\
\hline & & & & & & & & \\
\hline 1 & 33.4 & 28.9 & 28.0 & 12.9 & 37.0 & 41.1 & 18.4 & 9.0 \\
\hline 2 & 34.6 & 9.3 & 2.0 & 3.1 & 2.3 & 3.1 & 3.0 & 3.1 \\
\hline 3 & 28.8 & 10.6 & 8.0 & 7.9 & 11.4 & 6.4 & 8.1 & 3.5 \\
\hline 4 & 22.3 & 28.0 & 30.0 & 9.7 & 41.1 & 52.8 & 46.0 & 4.3 \\
\hline 5 & 30.0 & 16.9 & 29.0 & 13.9 & 35.0 & 17.2 & 20.2 & 4.3 \\
\hline 6 & 155.0 & 149.6 & 70.0 & 179.3 & 157.0 & 172.7 & 169.4 & 77.2 \\
\hline 7 & 24.6 & 16.0 & 26.0 & 11.0 & 40.2 & 16.3 & 41.8 & 14.6 \\
\hline 8 & 33.5 & 12.4 & 1.8 & 5.1 & 19.9 & 8.8 & 7.6 & 5.8 \\
\hline 9 & 24.0 & 13.3 & 9.7 & 7.9 & 26.0 & 11.2 & 13.1 & 6.4 \\
\hline 10 & 8.7 & 15.6 & 9.1 & 3.2 & 3.5 & 4.1 & 3.1 & 2.4 \\
\hline 11 & 34.7 & 37.4 & 4.7 & 3.8 & 7.5 & 3.8 & 4.2 & 2.5 \\
\hline 12 & 11.3 & 17.8 & 1.7 & 3.4 & 3.9 & 2.7 & 2.6 & 2.9 \\
\hline 13 & 74.2 & 20.3 & 5.1 & 3.7 & 73.0 & 81.4 & 80.1 & 9.5 \\
\hline 14 & 16.4 & 8.4 & 2.8 & 4.0 & 6.7 & 4.6 & 59.0 & 3.0 \\
\hline 15 & 11.2 & 8.6 & 4.1 & 3.4 & 4.0 & 3.8 & 70.8 & 2.4 \\
\hline 16 & 10.0 & 14.7 & 2.2 & 3.6 & 2.9 & 2.4 & 35.0 & 2.4 \\
\hline 17 & 31.8 & 10.8 & 42.0 & 16.8 & 27.2 & 56.5 & 95.0 & 11.2 \\
\hline 18 & 33.7 & 12.0 & 6.2 & 2.9 & 12.0 & 6.4 & 45.0 & 3.2 \\
\hline 19 & 15.0 & 8.0 & 39.2 & 25.6 & 32.4 & 17.9 & 76.0 & 15.1 \\
\hline 20 & 14.5 & 12.7 & 2.8 & 3.9 & 6.1 & 4.2 & 67.0 & 2.2 \\
\hline
\end{tabular}

Table 4. Dry matter yield, concentration of Fe in plant tissue and Fe uptake by maize (Zea mays L.).

\begin{tabular}{|c|c|c|c|c|}
\hline Soil No. & Dry Matter Yield & Nutrient Content & Fe Uptake & Fe Uptake \\
\hline & $\left(\mathrm{g} \mathrm{pot}^{-1}\right)$ & $\left(\mu g^{-1}\right)$ & $\left(\mathrm{mg} \mathrm{pot}^{-1}\right)$ & $\left(\mu \mathrm{kg}^{-1}\right)$ \\
\hline 1 & 4.9 & 22.4 & 0.11 & 275 \\
\hline 2 & 3.5 & 20.0 & 0.07 & 175 \\
\hline 3 & 6.2 & 33.9 & 0.21 & 525 \\
\hline 4 & 5.1 & 21.6 & 0.11 & 275 \\
\hline 5 & 4.9 & 26.5 & 0.13 & 325 \\
\hline 6 & 4.1 & 19.5 & 0.08 & 200 \\
\hline 7 & 4.3 & 20.9 & 0.09 & 225 \\
\hline 8 & 5.7 & 28.1 & 0.16 & 400 \\
\hline 9 & 5.8 & 25.9 & 0.15 & 375 \\
\hline 10 & 6.1 & 24.6 & 0.15 & 375 \\
\hline 11 & 5.2 & 25.0 & 0.13 & 325 \\
\hline 12 & 3.5 & 17.1 & 0.06 & 150 \\
\hline 13 & 6.7 & 34.3 & 0.23 & 575 \\
\hline 14 & 4.6 & 28.3 & 0.13 & 325 \\
\hline 15 & 6.9 & 34.8 & 0.24 & 600 \\
\hline 16 & 6.8 & 29.4 & 0.20 & 500 \\
\hline 17 & 7.5 & 44.0 & 0.33 & 825 \\
\hline 18 & 3.9 & 15.4 & 0.06 & 150 \\
\hline 19 & 6.3 & 27.0 & 0.17 & 425 \\
\hline 20 & 5.9 & 27.1 & 0.16 & 400 \\
\hline
\end{tabular}


Agric. Biol. J. N. Am., 2011, 2(8): 1244-1250

Table 5. Linear correlation coefficients ( $r$ ) between Fe uptake and the selected extractants.

\begin{tabular}{|c|c|c|c|c|c|c|c|c|}
\hline & Fe uptake & DTPA & $0.1 \mathrm{~N} \mathrm{HCl}$ & $\begin{array}{c}\mathrm{NaOCl} \\
(\mathrm{pH} 5.5)\end{array}$ & $\begin{array}{c}\mathrm{NaOCl} \\
(\mathrm{pH} 6.0)\end{array}$ & $\begin{array}{c}\mathrm{NaOCl} \\
(\mathrm{pH} 6.5)\end{array}$ & $\begin{array}{c}\mathrm{NaOCl} \\
(\mathrm{pH} \\
7.0) \\
\end{array}$ & $\begin{array}{c}\mathrm{NaOCl} \\
(\mathrm{pH} 8.0)\end{array}$ \\
\hline DTPA & $-0.15 n s$ & - & & & & & & \\
\hline $0.1 \mathrm{~N} \mathrm{HCl}$ & $-0.29 n s$ & $0.90^{* *}$ & - & & & & & \\
\hline $\begin{array}{c}\mathrm{NaOCl} \\
(\mathrm{pH} 5.5)\end{array}$ & $-0.01 n s$ & $0.61^{* *}$ & $0.68^{* *}$ & - & & & & \\
\hline $\begin{array}{l}\mathrm{NaOCl} \\
(\mathrm{pH} 6.0)\end{array}$ & $-0.20 \mathrm{~ns}$ & $0.88^{* *}$ & $0.95^{* *}$ & $0.78^{* *}$ & - & & & \\
\hline $\begin{array}{l}\mathrm{NaOCl} \\
(\mathrm{pH} 6.5)\end{array}$ & $-0.12 n s$ & $0.92^{* *}$ & $0.87^{* *}$ & $0.78^{* *}$ & $0.88^{* *}$ & - & & \\
\hline $\begin{array}{c}\mathrm{NaOCl} \\
(\mathrm{pH} 7.0)\end{array}$ & $0.01 \mathrm{~ns}$ & $0.91^{* *}$ & $0.86^{* *}$ & $0.77^{* *}$ & $0.86^{* *}$ & $0.96^{* *}$ & - & \\
\hline $\begin{array}{c}\mathrm{NaOCl} \\
(\mathrm{pH} 8.0)\end{array}$ & $0.23 \mathrm{~ns}$ & $0.67^{* *}$ & $0.63^{* *}$ & $0.68^{* *}$ & $0.74^{* *}$ & $0.74^{* *}$ & $0.79^{* *}$ & - \\
\hline $\begin{array}{c}\mathrm{NaOCl} \\
(\mathrm{pH} 9.5)\end{array}$ & $-0.18 n s$ & $0.90^{\star *}$ & $0.94^{* *}$ & $0.79^{\star *}$ & $0.99^{\star *}$ & $0.92^{* *}$ & $0.88^{* *}$ & $0.76^{\star \star}$ \\
\hline
\end{tabular}

** Significant at the 0.01 level.

ns $=$ not significant at the 0.05 level

Table 6. Linear correlation coefficients ( $r$ ) between the selected extractants and some physicochemical properties of the humid zone soils of South-Western Nigeria.

\begin{tabular}{|c|c|c|c|c|c|c|c|c|}
\hline $\begin{array}{c}\text { Soil } \\
\text { properties }\end{array}$ & DTPA & $0.1 \mathrm{~N} \mathrm{HCl}$ & $\begin{array}{c}\mathrm{NaOCl} \\
(\mathrm{pH} 5.5)\end{array}$ & $\begin{array}{c}\mathrm{NaOCl} \\
(\mathrm{pH} 6.0)\end{array}$ & $\begin{array}{c}\mathrm{NaOCl} \\
(\mathrm{pH} 6.5)\end{array}$ & $\begin{array}{c}\mathrm{NaOCl} \\
(\mathrm{pH} 7.0)\end{array}$ & $\begin{array}{c}\mathrm{NaOCl} \\
(\mathrm{pH} 8.0)\end{array}$ & $\begin{array}{c}\mathrm{NaOCl} \\
(\mathrm{pH} 9.5)\end{array}$ \\
\hline $\mathrm{pH}$ & $0.59^{* *}$ & -0.39 ns & $-0.18 \mathrm{~ns}$ & $-0.37 \mathrm{~ns}$ & $-0.45^{*}$ & $-0.42 \mathrm{~ns}$ & -0.08 ns & $-0.38 \mathrm{~ns}$ \\
\hline Org. C & $0.19 \mathrm{~ns}$ & $0.07 \mathrm{~ns}$ & $0.59^{* *}$ & $0.16 \mathrm{~ns}$ & $0.40 \mathrm{~ns}$ & $0.35 \mathrm{~ns}$ & $0.367 \mathrm{~ns}$ & $0.25 \mathrm{~ns}$ \\
\hline Sand & $0.02 \mathrm{~s}$ & $0.17 \mathrm{~ns}$ & $0.37 \mathrm{~ns}$ & $0.31 \mathrm{~ns}$ & $0.24 \mathrm{~ns}$ & $0.20 \mathrm{~ns}$ & $0.38 \mathrm{~ns}$ & $0.33 \mathrm{~ns}$ \\
\hline Silt & $-0.069 n s$ & $-0.31 n s$ & $-0.15 n s$ & $-0.28 n s$ & $-0.16 \mathrm{~ns}$ & $-0.10 n s$ & $-0.17 n s$ & $-0.31 n s$ \\
\hline Clay & $0.02 \mathrm{~ns}$ & $-0.05 n s$ & $-0.39 n s$ & $-0.24 n s$ & $-0.22 n s$ & $-0.20 n s$ & $-0.39 n s$ & $-0.24 n s$ \\
\hline
\end{tabular}

** Significant at the 0.01 level

*Significant at the 0.05 level

ns $=$ not significant at the 0.05 level

\section{CONCLUSION}

The study showed that $\mathrm{Fe}$ extracted by $\mathrm{NaOCl}$ at $\mathrm{pH}$ 8.0 was preferable to that extracted by the conventional extractants (DTPA and $0.1 \mathrm{~N} \mathrm{HCl}$ ), though with a weak correlation with plant $\mathrm{Fe}$ uptake. Because of the availability of $\mathrm{NaOCl}$ and the simplicity of the extraction procedure, the $\mathrm{NaOCl}$ method buffered at $\mathrm{pH} 8.0$ could be used as a replacement for the two current procedures for humid zone soils of South-Western Nigeria.

\section{ACKNOWLEDGEMENTS}

The authors wish to acknowledge the financial assistance of the Universities of Ibadan and Buea.
We also thank Professor G.O. Adeoye for his advice and assistance during soil sampling. Technical assistance by Mr Paulinus Igenegbai is also gratefully acknowledged.

\section{REFERENCES}

Agboola, A.A and Fube, H.N (1982). Effect of iron yield and performance of upland rice in south-western Nigeria. Fert. Res. 4: 119-126.

AOAC (1970). Official methods of analysis, $11^{\text {th }}$ edition, Washington D.C.

Aubert, $\mathrm{H}$ and Pinta, M (1977). Trace elements in soil. Elsevier Publishing Co. Amsterdam.

Banjoko, V.A (1981). Effects of moisture regime on the extractable iron content in selected soils of southwestern Nigeria. Nigerian J. Soil Sci. 2: 13-23. 
Bimie, A.C and Paterson, E (1991). The mineralogy and morphology of iron and manganese oxides in an imperfectly drained Scottish soil. Geoderma 50: 219237.

Burrman, $P$ (1985). Carbon/sesquioxide ratios in organic complexes and the transition albic-spodic horizon. Soil Sci. 36: 255-260.

Chaignon, V., Di Malta, D and Hinsinger, P (2002). Fedeficiency increases $\mathrm{Cu}$ acquisition by wheat cropped in a Cu-contaminated vineyard soil. New Phytol. 154: 121-130.

Cottenie, A., Kang, B.T., Kiekens, L and Sajjapongse, A (1981). Micronutrient status. In: Greenland DJ (ed) Characterisation of soils in relation to their classification and management. Oxford University Press, Oxford, pp149-163.

FAO (1983). Fertilizer and Plant Nutrition Bulletin 7:23-81.

IITA (1979). Selected methods for soils and plant analysis. Manual series No. 1. International Institute of Tropical Agriculture, Ibadan, Nigeria.

Jackson, M.L (1958). Soil chemical analysis. Printice-Hall, Inc., Englewood Cliffs, NJ.

Kang, B.T., Abifarin A.O and Sajjapongse, A (1976). Iron deficiency problems with upland rice in westernNigeria. Nigerian Agric. J. 13: 3-15.

Kashirad, A and Marschner, H ( 1974). Iron nutrients of sunflower and corn plants in mono and mixed culture. Plant Soil 41: 91-101.

Lavkulich, M.L and Wiens, J.H (1970). Comparison of organic matter destruction by hydrogen peroxide and sodium hypochlorite and its effects on selected mineral constituents. Soil Sci. Soc. Am. Proc. 34: 755-758.

Lindsay, W.L (1972). Inorganic phase equilibria of micronutrients in soils. pp. In: Mortvedt et al (eds) Micronutrients in Agriculture, eds. J.J.., 41-57. Soil Science Society of America: Madison. Wisconsin

Lindsay, W.L and Norvell, W.A (1978). Development of a DTPA soil test for zinc, iron, manganese and copper. Soil Sci. Soc. Am. J. 42: 421-428.

Mandal, L.N (1961). Transformation of iron and manganese in waterlogged rice soils. Soil Sci. 91: 121-129.
O'Conner, G.N., Lindsay, W.L and Olsen, S.R (1971). Diffusion of iron and iron chelates in soil. Soil Sci. Soc. Am. Proc. 35: 407-410.

Oertli, J.J and Opoku, A.A (1974). Effect of micronutrient ions on the availability of iron from a chelated source. Soil Sci. Soc. Am. Proc. 38: 597-602.

Olaitan, S.O., Lombin, G and Onazi, O.C (1984). Introduction to Tropical Soil Science. Macmillan Publishers Ltd. London and Basingstoke.

Olsen, R.A., Bennett, J.H., Blume, D and Brown, J.C (1981). Chemical aspects of the iron stress response mechanism in tomatoes. J. Plant Nutr. 3: 905-921.

Omueti, J.A.I (1980). Sodium hypochlorite treatment for organic matter destruction in tropical soils of Nigeria. Soil Sci. Soc. Am. J. 44: 878-880.

Omueti, J.A.I (1981). The effect of $\mathrm{H}_{2} \mathrm{O}_{2}$ and $\mathrm{NaOCl}$ pretreatment for organic matter removal on selected mineral constituents in some Nigerian soils. Commun. Soil Sci. Plant Anal. 12: 139-146.

Omueti, J.A.I and Lavkulich, L.M (1988). Identification of clay minerals in soils: The effect of sodiumpyrophosphate. Soil Sci. Soc. Am. J. 52: 285-287.

Pauwels, J.M., Van Ranst, E., Verloo, M and Mvondo-Ze, A.D (1992). Manuel de la Laboratoire de pédologie: méthodes d'analyses des sols et de plantes, Equipement, Gestion de stocks de verrerie e de produit chimique. Publication Agricoles, Dschang, Cameroun, 265pp.

Smith, A.J and Montgomery, R.F (1962). Soils and land use of central western Nigeria. Ibadan, Nigeria: The Government Printer.

Schnitzer, M and Skinner, S.I.M (1965). Organo-metallic interactions in soils. 4. Carboxyl and hydroxyl groups in organic matter and metal retention. Soil Sci. 99: 278-284.

Tening, A.S., Omueti, J.A.I., Tarawali, G and MohamedSaleem, M.A (1995). Potassium status of some selected soils under different land-use systems in the subhumid zone of Nigeria. Commun. Soil Sci. Plant Anal. 26: 657-672.

Thoiron, S., Pascal, N and Briat, J.F (1997). Impact of iron deficiency and iron re-supply during the early stages of vegetation development in maize (Zea mays L.). Plant Cell Environ. 20: 1051-1060 